
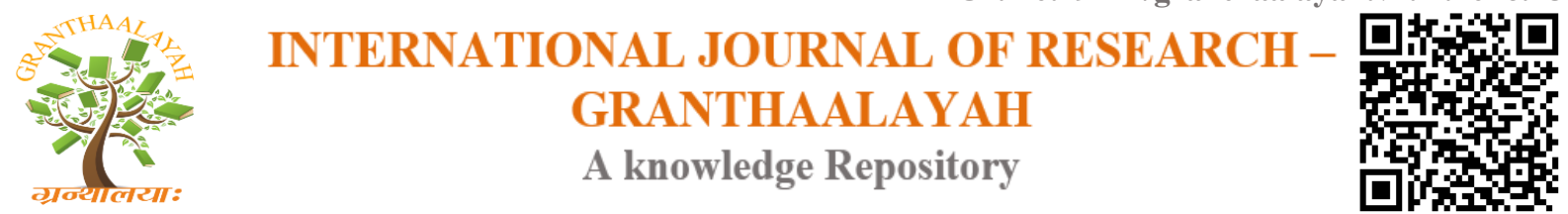

Management

\title{
CHALLENGES OF INTEGRATING RESPONSIBLE MANAGEMENT EDUCATION IN HIGHER EDUCATION INSTITUTIONS OF UTTAR PRADESH, INDIA
}

\author{
Dr. Ajai Prakash ${ }^{* 1}$, Archana Yadav ${ }^{2}$ \\ ${ }^{*}$ Faculty, Department of Business Administration, University of Lucknow, INDIA \\ 2 JRF, Department of Business Administration, University of Lucknow, INDIA
}

\begin{abstract}
India is facing a big debate on various social, economic and political issues which remained around corruption and poverty; how they can be eradicated from our society. Uttar Pradesh (U.P.) is the most populous state of our country with over $16.4 \%$ of countries total population. Moreover with 9\% of the country's total geographical area, U.P. is the 4th largest state of our country. The median age of U.P. is 20 whereas that of India is young 24 years as in 2011. Though U.P. is the youngest state in India and has a rich cultural heritage but when it comes to literacy and gross enrolment in higher education, it is far behind other states. In order to create a responsible environment, management education can work as a very effective tool. In order to tackle the challenges faced globally such as corruption, poverty and workforce diversity, the United Nations has developed Responsible management initiative. The objective of this paper is to present the structure and different channels of management education in India with special reference to U.P. state. The focus is on identifying critical factors in integrating responsible management education in Higher Educational institutions with reference to sustainable development.
\end{abstract}

Keywords:

Responsible Management Education (RME), Principles for Responsible Management Education (PRME), University Grants Commission (UGC), Higher Education (HE).

Cite This Article: Dr. Ajai Prakash, and Archana Yadav, "CHALLENGES OF INTEGRATING RESPONSIBLE MANAGEMENT EDUCATION IN HIGHER EDUCATION INSTITUTIONS OF UTTAR PRADESH, INDIA” International Journal of Research - Granthaalayah, Vol. 4, No. 1 (2016): 171-177.

\section{INTRODUCTION}

Uttar Pradesh is considered among most highly populated states in India and in terms of geographical area is the fourth largest state in our country. But, when it comes to literacy rate, number of HE institutions in UP and Gross Enrolment rate (GER), the state is far behind other states of India. There are various socio- economic and political factors which are hindering the 
growth of the state. Corruption, poverty, gender disparity and unemployment are some of the factors responsible for poor literacy rate and lack of good quality management institutions in U.P. Lack of qualified faculties and low focus on research are also affecting this sector. There is large discrimination in our society in terms of rural and urban population, gender disparity and religion. The focus is on finding ways to implement responsible management initiatives in the state of U.P. which would in a way help in eradicating corruption, poverty and gender disparity from the society. In this paper, various challenges in incorporating RME in various $\mathrm{HE}$ institutions of Uttar Pradesh are also discussed.

\section{UTTAR PRADESH AND ITS EDUCATION}

U.P. is the $4^{\text {th }}$ largest state in terms of geographical area and has a very rich cultural heritage. The state has a large variety of geographical land and cultural diversity. The state has an important role in the field of politics, agriculture, culture, industry, education and tourism of India. The state of UP with $16.4 \%$ of country's total population, is the most highly populated state in our country. The state with $9 \%$ of county's total geographical area covering $2,94,411 \mathrm{sq}$. $\mathrm{km}$. is the $4^{\text {th }}$ largest state in terms of geographical area. The total area of state comprises of 83 districts, 901 developmental blocks and 112,804 villages. The density of population in the state of UP is 473 people per square kilometres whereas that of country is 274 .

At the higher and technical education level, UP has 16 general universities, 3 technical universities and 2 IIT's (Indian Institute of Technology) at Kanpur and Varanasi, one IIM (Indian Institute of Management) at Lucknow, one IIIT (Indian Institute of Information Technology) and large number of various other Engineering ,Polytechnic and Industrial Training institutes. These higher and technical education institutes help in providing opportunities to students for higher education.

Since Independence, higher education sector has seen tremendous growth in terms of Institutional capacity. Since Independence, the number of HE institutes has increased 18 times from 27 in 1950 to 504 in 2009. In the state, there are 42 Central Universities, 243 State Universities, 53 State private universities, 130 Deemed Universities, 33 Institute of National importance (Established by act of parliament) and Five institutes (Established by various state legislations). Providing and ensuring facilities for Higher education to all citizens of country is the shared responsibility of both centre and the State Government.

The main constituents of University Level Institutions at present are Central Universities, State Universities, University - Level Institutions and Deemed to be Universities.

\section{EMERGENCE OF NEW TYPE OF HIGHER EDUCATION PROVIDERS}

In the Post-1980 era, various types of new Higher Education providers evolved. After this period various distance- education programs gained popularity. Due to shortage quality educational institutions, various public universities and colleges also started offering self- finance programs to cater growing demand for education by students. Various Foreign Universities also started offering programs in India by setting up their own centres or in coordination with various Indian universities and institutes. In India, after 1980s the non - university sector saw a huge growth 
due to the increase in demand of skilled labours from our growing economy. As a result, a large number of Polytechnic and Industrial Training Institutions evolved in India for providing training to become supervisors in technical or respective skills. Another reason of increase in number of institutions of higher education is due to contribution of private sector.

\section{STRUCTURE OF MANAGEMENT EDUCATION INSTITUTIONS}

At present there are six types of Management Education Institutions in India. These are as follows:

1.) Indian Institute of Management (IIMs)

2.) University Departments of Management Studies

3.) Colleges (Government or Private) affiliated to Universities

4.) Private or Government Institutes approved by All India Council for Technical Education (AICTE)

5.) Private Colleges and Institutes not affiliated to any universities nor approved by All India Council for Technical Education AICTE

6.) Private Colleges or Institutes offering MBA courses in India in collaboration with foreign universities where degree/diploma/certificate is awarded by the foreign university.

\section{RESPOSIBLE MANAGEMENT EDUCATION}

The RME initiative motivates the educational institutions to implement and provide a platform for sharing, action- oriented learning on responsible management education.

RME initiative on Anti-corruption in curriculum change tries to incorporate integrated anticorruption guidelines for curriculum change in Management Education Institutions around the world. It also aims at inaugurating a line of development on climate change and curriculum change for the transversal introduction of climate change issues in the curriculum of business schools.

The RME initiative tries to incorporate the issue of poverty in the curriculum so that management professionals are well- equipped with the environment in which businesses operates.

RME helps to understand and equip the future managers to manage the businesses sustainably. By implementing this both businesses and society are going to be benefited. RME initiative helps and motivates $\mathrm{HE}$ institutions to engage in conceptual and empirical research that helps organisations in the effective implementation of all three dimensions of sustainability i.e. social, economic and environmental.

The organisations now-a-days are very largely affected by corrupt business practices. The Management Education can act as a strong driver of change for creating a responsible environment for doing business. United Nations has started and developed the responsible management education initiative which aims at eradicating corruption, poverty and gender disparity. The RME initiative will help to eradicate these evils from society by inculcating thoughts against these evils in the minds of students from an early stage. 


\section{CHALlENGES IN INTEGRATING MANAGEMENT EDUCATION WITH ISSUES OF SUSTAINABLE DEVELOPMENT}

The challenges which are faced while integrating RME in higher educational institutions in Uttar Pradesh are as follows:

- Lack of quality Educational Institutions: In India, the top six states in terms of highest number of colleges are Andhra Pradesh, Karnataka, Maharashtra, Rajasthan, Uttar Pradesh and Madhya Pradesh. But in U.P. the colleges per lakh population are only 17 which make the state lowest among all six states.

Out of the total 621 Universities in India, UP has just 4 Central universities, 3 Institutes of National Importance, 23 State public universities, 1 State open university, 14 State private universities, 1 Institute established under state legislature act, 3 Government deemed Universities and 7 Private deemed universities (Grand Total: 56). UP has just 1359 Average enrolment per college.

UP is the most populous state in India but still the state has large shortage of good quality of Educational Institutions, Universities and Colleges here to address the growing educational needs of its youth population.

- Faculty shortage: In India, Pupil- teacher ratio (PTR) in Universities and colleges is 26.4 and when we talk about UP state the ratio is further declined. The faculty shortage not only affects the performance of students but it also hinders the growth of society at large.

- Education System in ancient India: The education system in ancient India was highly upgraded and advanced as is evident from centres of learning that existed in different parts of country ranging from Buddhist monasteries of the $7^{\text {th }}$ century $\mathrm{BC}$ up to the $3^{\text {rd }}$ Century AD Nalanda. At that time, all these centres of learning were large and had several faculties. Many historians state that these centres of learning have a remarkable resemblance with European Medieval universities that were developed much later. These centres of learning which were the backbones of ancient education system in India; vanished slowly due to invasions, battles and disorder in the country. Till the eighteenth century, our country had three distinct traditions of advanced scholarship such as Hindu Gurukulas, Buddhist Viharas and Quranic Madarasas.

- Absence of an efficient Accreditation system: At present, one of the most pressing issues is to identify a fair process which can be adopted for the implementation of an effective accreditation system so that quality of various HE Institutions can be ensured. The accreditation system should be fair, transparent and independent. As the number of $\mathrm{HE}$ institutions is increasing rapidly, it requires a specialised body to conduct accreditation system instead of the exiting AICTE carrying it out along with other activities. 
In order to assist students in selecting a good management institution because of the mushrooming growth of colleges in India, National Knowledge Commission (NKC) has recommended rating as an additional measure to inform the students, the parents and public about the quality of management institutions in country. Some of the management institutions did not even meet the minimum requirements for the acceptable quality. If the disclosure of information of rating will be made mandatory, then it will help a lot of the stakeholders including students and recruiters in decision-making.

If rankings and grading are made any indicator of quality, then Indian institutions of higher learning has a long way to go, both nationally and internationally. A remarkable $89 \%$ of India's accredited Colleges and Universities are internationally graded either 'average' or 'below average'; raising serious doubts about their quality. Punjab University which is among India's top rated Universities ranks between 226 and 250, the National Assessment and Accreditation Council's (NAAC) assessment is no better, with $62 \%$ of universities accredited rated average or below average. Moreover, the actual picture is likely to be even worse since only 179 varsities and 5,224 colleges have valid accreditation out of 630 varsities and 33,000 colleges.

- Serious Financial and Infrastructural Crunch: This is a well-known fact that not only the state of Uttar Pradesh but the entire country is facing serious problems due to shortage of finances and lacks of good infrastructure as most of the institutes are government- run.

NAAC director professor A N Rai also said, "Only 11\% of our accredited institutions are ' $A$ ' grade, while $71 \%$ are ' $B$ ' grade. The remaining $18 \%$ are in the lowest ' $C$ ' grade. This shows the poor quality of the HE institutions. We have to consider various parameters while assessing quality of HE institutions. Since most of the institutions are governmentrun, there is a serious financial and infrastructure crunch which adversely affects the assessment and lowers the grade. But we have to appreciate the fact that despite being voluntary, they came for the assessment."

- Arrival of New Technologies: The students and the curriculum should be regularly upgraded to meet the changing demands of environment and this can be done with the help of Technology enabled learning. This objective can be achieved with the help of techniques such as introducing various specialised courses for PWD students.

Also various ICT techniques such as Video conferencing and various other Audio visual techniques can be introduced at $\mathrm{HE}$ level to enhance the quality and standard of teaching across the state. The technology enabled learning will help to make not only UP but the entire country a Knowledge economy. Technology enabled learning may help India to emerge as a Global leader in HE in the years to come and it will also enhance the quality of higher educational institutions.

- Lack of focus on Research and Development: Only 1.9\% Colleges run Ph.D. program and 33.4\% Colleges run Post Graduate Level programmes. 77844 students are enrolled in 
Ph.D. that is less than $0.5 \%$ of the total student enrolment and in UP there are only 6312 students.

The HE Institutions do not have culture that is supportive of research. Imbibing a research culture requires a good library support system. Scholars should be motivated and invited to undertake research in certain areas of national interest. With respect to the research grant procedure, there is a need to support more to individual project proposals. Those institutions which have adequate support system to start Ph.D. program should be encouraged by providing better assistance.

So, the focus should be on research and innovation, development of research parks, promoting centers of excellence and global linkages.

- Absence of Trained Faculties: In order to create good teachers for HE Institutions, the faculty development programmes must be conducted at a large scale. Presently the teachers in the B- Schools are prepared on a trial \& error basis at the cost of present generation of students who are the real sufferers. Some studies should also be done to find out ways in which the quality of existing Faculties can be improved as till date no significant study has been done in this regard.

- Poor industry linkages: With the help of monitoring of quality of Summer Internship programs (which is already part of various technical courses) and various other On the Job Training (OJT) programs, the industry linkages can be strengthened. It will also help in making students more employable as there is yearly increase in number of graduates passing out from various Colleges and Universities but the skills set required in them by the companies is not appropriate which is the main cause of rising unemployment rate. This could be achieved by implementing and focusing on Proactive Academia Industry interactions.

- Lack of transparency at Corporate Level: It is generally found that the companies do not actually implement and adopt various standard practices that they are supposed to follow. Even their practices do not match with their own "Vision, Mission and Objectives" that they set in the initial stage. This practice should be stopped and companies should actually play an active role in fulfilling their responsibility towards society at large.

- Funding issues and shortages: The Government offers a number of scholarships/grants and loans to meritorious students as part of their Student financing initiative but actually in practice the number of students getting benefited is very minimal due to corruption and red- tapism in the state. So, efforts should be made to address this issue and eradicate the ground problems that students are facing.

- Lack of Readiness of Higher Education Institutions in adopting RME: The total number of participants listed in United Nations Principles of RME (PRME) initiative are 532 whereas from India only $28 \mathrm{HE}$ institutions are part of this initiative (very few from UP). In UP there are large number of Universities and Colleges and now the focus should be shifted on making HE institutions determined to implement RME which inspires internationally accepted values in the form of measures aimed at imparting anti corrupt, 
anti-poverty and gender equal practices. The higher educational institutions should try to upgrade themselves as per the changing requirements and become more prompt to implement RME.

\section{CONCLUSION}

In today's $21^{\text {st }}$ Century, India's higher education is undergoing a major transition. Internationalization, cross cultures, strategic alliances, partnership \& mergers are the new trends in management education. But at the same time lack of research and good quality faculty are plaguing the sector. There is wide disparity in terms of rural-urban, gender and communities. India's Gross Enrolment ratio (GER) in HE is $19.4 \%$ which not only significantly lags behind that of developed countries such as the US, Switzerland, Japan and the UK, but also that of developing countries including China, Brazil, Malaysia and the Philippines. So, in order to address these issues the focus now should be on implementing RME in HE Institutions across states.

\section{REFERENCES}

[1] Pawan Agarwal. "Higher Education in India - The need for Change” Working paper no. 180, 2006

[2] National Knowledge Commission (NKC) report on Working Group on Management Education, 2005

[3] FICCI Higher Education Summit 2012 report on Higher Education in India: Twelfth Five Year Plan (2012-2017) and beyond

[4] MHRD report on "Quest for quality in higher education" presented in Conference of Governors, 14th February, 2014

[5] "State at a glance", retrieved February 21, 2014 from http://upgov.nic.in

[6] "University and Higher Education", retrieved February 21, 2014 from http://mhrd.gov.in

[7] “Participants \& PRME Working Group and Regional Chapters", retrieved February 21, 2014 from http://unprme.org

[8] MHRD, “All India Survey on Higher Education (AISHE)” (2010-11)

[9] Manash Pratim Gohain, 2014, "Indian universities second-grade? - 89\% of NAACAccredited Institutes Are 'Average’ or Worse”, 21 February, Pg. - 6. 